\title{
Flexible Work Designs, as a Strategic Tool for Twenty-First-Century Intricacies: A Descriptive Analysis amongst Healthcare Employees in the United Arab Emirates
}

\section{Hima Parameswaran}

Assistant Professor, City University College of Ajman, Sheikh Ammar Road, Al Tallah - 2, Ajman, United Arab Emirates h.parameswaran@cuca.ae

\begin{abstract}
Many of the 21 ${ }^{\text {st }}$ Century's intricacies can be explained by their strategic employment relationships. The present study discusses the necessity of flexible work designs by utilizing and maintaining the workforce to their full potential. Keeping this in mind, this study was conducted in randomly selected health sectors, in the UAE. Along with the models related to this subject and a questionnaire of 300 respondents, by stratified proportional sampling, provided a deep understanding of the outlooks of employees in their work designs. A descriptive analysis, using SPSS 24.0, maintained the significance level of the latent variables, such as, organizational flexibility, and cognitive flexibility, to the independent variable, flexible patterns. The findings confirmed the alignment of models extracted from the theories to the variables discussed in the questionnaire. Moreover, all the hypotheses crafted for the study have accepted. Thus, the study proved that a flexible workforce requires management to be tactical, create various work designs on demand, and develop requisite skills to undertake this task. Furthermore, it communicates that productivity and career responsibility can increase while fatigue and staff turnover can lessen if the work designs are strategically crafted, within the selected companies.
\end{abstract}

Keywords: Flexible work designs; Organizational flexibility; Cognitive flexibility; Productivity; Career responsibilities

\section{Introduction}

Society depends on organizations for its endurance. The standard of living of the citizens in any nation is linked with the adaptability of the organizations. The competence of organizations, in turn, measures the competencies of their employees. Hence, organizations need to strive hard to achieve the goals by specific ways in organizing and managing their work designs [1] [2]. Much of the current literature supports the view that employee engagement, involvement and 
participation are crucial in management practices towards organizational competence [3-7]. Additionally, organizations in the present era are making swift changes in utilizing their resources due to the increase in the economic volatility, and new technology coupled with shortage of skills. This leads to the evolution of restructuring the traditional HRM functions into strategic, and operational levels. It highlights the alignment between strategic management and strategic human resource management, which can be executed through an effective co-operation between HR professionals and line managers. The economy of a country is dependent on its firms' growth and sustainability [8-10]. Human capital has a vital role in the organizations to develop strategies and operationalize them. In fact, there are numerous models of SHRM that supports the fit between HRM practices and effective utilization of human resources. Unlike the traditional approach in analyzing the internal factors only, the studies identified that flexible work design can create innovative practices in organizations by external scanning.

According to Ursell (1991), flexible labor in organization needs a strategic planning and it involves numerous processes. It can be a greater variety, in the time periods of employment; utilization of individual skills in a varied manner; employment contracts as franchise; subcontractor relations; part time or temporary employees [11]. Moreover, this includes both quantitative (hard) and qualitative (soft) approaches. It emphasizes on organizational strategies as hard approach and talent management as soft approach [12] [13]. Thus, the use of flexible work arrangements is a holistic approach and can lead to changes in all aspects; organizational, cultural, operational, and managerial. Moreover, the overlapping or increasing use of multiple flexible patterns in organizations helps the management to response to changing demands. At the same, it is a question that organizations are ready for this flexibility in its work design. Considering the importance of flexible work designs, the objectives crafted for the study are as follows:

To identify the variables for Cognitive flexibility in organizations

- $\quad$ To find the variables for Organizational flexibility in organizations

- To explore the significance of flexible work-design in organizations

\section{Review of Literature}

In fact, it is not easy to define flexibility in organizations as it includes wide range of issues and analysis. According to Pilbeam and Corbridge (2006) [14] flexibility is the ability of the organization to adapt to its size, structure, responsiveness, and rate of the people inputs required to achieve organizational objectives. In traditional SHRM models, one of the models that strongly supports the view of flexibility is model of 'fit' versus 'flexibility'. Here it focused on two types of congruence or fit, such as, a vertical fit and a horizontal fit. The former fit implicates the alignment of 
HRM practices and the strategic management process. This directs the human resources towards the initiatives of the organization. The latter involves a fit amongst various HRM practices by efficiently allocating the resources (Wright and Snell, 1998) [15]. So, these models of fit have a direct link between needs, demands, goals, objectives, and structures (Nadler \& Tushman, 1980) [16]. However, various shifts due to environmental factors call for a flexible work design in companies for its adaptation. To support this fact, Snachez (1995) stresses flexibility as a wider perspective because it provides environmental scanning, detects challenges, and through this, it can modify its capabilities, and develop alternatives to manage changes [17]. To add to this, Wright and Snell (1998) designed an SHRM model in which it demands organizational flexibility in order to achieve a dynamic fit. The model focuses on strategies and employee behaviors and skills to achieve the mission and goals of the organization.

Literature provides several flexibilities exist in organizations where they overlap each other to maintain a competitive advantage. As mentioned earlier, companies need to change according to market demand and for this, management extends their ability to arrange and reorganize the tasks with adequate skill development programs. Contrary to Taylor's scientific management principles, this functional flexibility provides teambuilding, multi-skilling, re-skilling, and project working (Treu, 1992) [18]. When it comes to the quantitative approach, this is based on the principle of relating the workforce to the levels of economic activity easily and on short notice such as seasonal, part-time, casual, and subcontracted workers. In work-time flexibility, there is a closer correlation between labor utilization and production demands, without additional costs of hiring labor. Moreover, these overtime or shift time flexible designs can enhance work-life balance and job sharing (Legge, 1995) [19]. Furthermore, Atkinson (1984) argues on the need for financial flexibility as it determines the design of compensation and wage rates with respect to market rate [20]. Another flexibility, procedural flexibility focuses on changing severities in labor and employment patterns and contributes to industry policymaking and industrial relations (Woods, 1989) [21]. The work design that enhances and enables the establishment and development of amendment or public policies are termed regulatory flexibility. To add on, mobility flexibility involves a change in the work such as telecommuting or virtual teams can also enhance the employee engagement levels (Bamber, 1990) [22].

\subsection{Cognitive Flexibility}

From an individual perspective, employee value proposition (EVP) fulfills employees' needs, expectations, and aspirations. While constructing a successful EVP, tangible and intangible factors need to consider. As discussed earlier, while considering flexibility related to the package, it relates with the pay and benefits, role definition, job content, and the nature of work. The working experience entails role clarity, relationship with managers, respect for colleagues, and adaptation to 
diversity. Moreover, the leadership style provides freedom and respected behavior in their tasks. A work design with these factors and related feelings of the employees can relate to the mental frame or cognitive flexibility. Hence, employees can perform effectively by developing their skills and talents with these flexible designs. Furthermore, this flexibility has contributed to significant changes in the psychological contract between the employer and employee relationship (Ingham, 2006) [23]. It is important to identify whether the employees acquire new skills knowledge and competencies to the demands and expectations of the organizations (Rosseau, 1995) [24].

Owing to the significance of cognitive flexibility, the first hypothesis of the study is:

\section{H1: The EVP has a significant role in cognitive flexibility}

\subsection{Organizational Flexibility}

In a broader meaning, the structural response to the development of the flexible patterns towards the employee value proposition is termed organizational flexibility (Atkinson, 1984). This flexibility is dependent on all the above-mentioned work patterns. To be specific, a formal and informal organization system, physical environment, career opportunities, training, and development increase individual satisfaction and aspirations (Ingham, 2006). Moreover, the Australian Centre for Industrial Relations and Research and Training (ACIRRT) highlights that the new work designs to the changing labor market created an extensive transformation in the employee-employer relationship [25]. The "gold-collar workers", need good working conditions and developed systems as this group forms a company's strategic advantage. Hence, organizations must focus their employment systems, procedures, and organizational structures to guarantee they acquire these skills into the businesses (Scarbrough, \& Swan, 2003) [26]. Additionally, knowledge management creates an organizational culture in learning and change management. Research showed that it is an interexchange of knowledge between individuals who know and those who want to know (Davenport \& Prusak, 2001; Feher, 2002; Sandori, 2007) [27-29]. Moreover, leadership can make structural changes in organizations. It can be developed through experience, culture, and history through which more followers can be created. It streamlines the processes to achieve a common goal and increases individual performances. Leadership maintains an unequal distribution of power to activate the effort and behavior of followers to the desired goal. In Leader-member exchange theory (LMX), it emphasizes the entity perspective approach to leadership and relationships between leaders and followers. Also, it highlights that leadership is comprised of "three primary components: the characteristics of the leader; those of the follower; and the maturity of the leadership relationship" as it "occurs within the context of the leadership relationship [30-38]. 
Furthermore, the new flexible system encourages the flow of information and an open system through social networks, which can enhance competitiveness (Kelliher \& Anderson, 2008) [39]. According to Szabó and Hámori (2006), "at the information age, companies undergo constant transformation and reorganization, their strategy and organization are both flexible." [40]

Another development in the system approach is the High-involvement Work Systems (HIWSs) where employees feel more autonomy, self-designed teams (Gordery \& Parker, 2007) [41]. Considering this, the next hypothesis to test is:

\section{H2: The system approach has an imperative role in organizational flexibility}

\subsection{Flexible Work-Design}

Studies have shown that those organizations that utilize the workforce in a flexible manner can adapt to the changing environment. Research by the Institute for Employment Studies in the UK identified the development of a distinct organizational structure can reinforce the multiple forms of flexibility, which has mentioned above. To support this view, Thompson and McHugh argue that the coreperiphery model promotes a competitive advantage by developing a better employee relationship [42]. The new era with a great transformation due to economic and social changes, the impact reflects on the labor market and in turn affects the employer-employee relationship [43]. Employers frequently focus on person/organizational match to ensure the execution of strategic plans both in the short and long run. Employers constantly look for the personal abilities and knowledge that ensure the implementation of their strategic plans both in the short and long run [44]. At the same time, the talents or workforce management establishes the company's performance is maintained by employees' Knowledge, Skills, Abilities (KSAs) [45]. Unlike traditional work design, the new design takes the form of a core with a variety of peripheral activities to its changing environment. Numerous pieces of the literature indicated that in the developed countries like the UK and Australia these flexible work patterns are not much developed (Burgess, 1997) [46]. Seeing these facts, the third hypothesis of the study is:

\section{H3: Cognitive and organizational flexibility have a significant role in competitiveness}

\section{Research Methods}

The study utilizes a mixed approach, which consists of a close-ended questionnaire (Table 1) generated from profuse literature, and interviews with managers and leaders, by random sampling method. The data universe consists of 300 respondents from various health sectors located in Dubai, UAE. The first task was to do 
descriptive statistics to estimate the reliability and validity of the measures used in the research. Initially, an input model was created using AMOS 18 graphics. Later, the study tested the proposed research model by assessing the contributions and significance of the manifest variables' path coefficients. SPSS 20.0 was used to analyze the response from the sample. Another measure, Structural Equation Modelling (SEM) provides a confirmatory approach to the analysis of a structural theory bearing on some phenomenon. Moreover, the hypotheses are statistically tested to examine their consistency with the data through the goodness of fit measures. This allows the examination of a series of dependence relationships between exogenous (independent) and endogenous (dependent) variables simultaneously. This was done using the two-stage analysis in which the measurement model is first estimated and then the measurement model is kept fixed in the next step in which the structural model is estimated. The justification for this approach is that accurate representation of the indicators' reliability is best accomplished in two steps by avoiding the interaction of structural and measurement models. According to the usual procedures, the goodness of fit is measured by checking the statistical and substantive validity of estimates, the convergence of the estimation procedure, the empirical identification of the model, the statistical significance of the parameters, and the goodness of fit to the covariance matrix. A level of 0.05 was established, as a priority, for determining significance. Stratified proportional sampling was used in collecting the data as the study consists of employees from varying demography, which helps to recognize the disparity in employees' outlooks on mentioned latent variables.

\section{Analysis of Data}

As mentioned earlier, a Likert point scale questionnaire was distributed amongst the employees from the selected companies, and the related latent variables are expressed in Table 1 below;

Table 1

Measures for latent variables

\begin{tabular}{ll}
\hline Latent Variables & Related Factors \\
\hline Cognitive & $\begin{array}{l}\text { Q1. Do you have opportunities for systems development through } \\
\text { inputs, processes, feedback? }\end{array}$ \\
\cline { 2 - 2 } & $\begin{array}{l}\text { Q2. Do you have enough opportunities for competencies through } \\
\text { skill and knowledge development? }\end{array}$ \\
\cline { 2 - 2 } & $\begin{array}{l}\text { Q3. Do you have opportunities to work with leaders, managers, } \\
\text { customers at your organization? }\end{array}$ \\
\cline { 2 - 2 } & $\begin{array}{l}\text { Q4. Do you have opportunities to work in a team-learning } \\
\text { environment? }\end{array}$ \\
& $\begin{array}{l}\text { Q5. Do you have shared culture, values, and norms in your } \\
\text { organization? }\end{array}$ \\
\hline
\end{tabular}




\begin{tabular}{|c|c|}
\hline & $\begin{array}{l}\text { Q6. Do you have enough opportunities for technological } \\
\text { advancement competencies through skill and knowledge } \\
\text { development? }\end{array}$ \\
\hline \multirow[t]{7}{*}{$\begin{array}{l}\text { Organizational } \\
\text { flexibility }\end{array}$} & $\begin{array}{l}\text { Q7. Do you have a strong urge for learning from observing others, } \\
\text { managers, leaders? }\end{array}$ \\
\hline & Q8. Is your work monotonous or time-consuming? \\
\hline & Q9. How extent you are socialized (informally) with your team? \\
\hline & Q10. Do you have a flexible work environment? \\
\hline & Q11. Are you creative/innovative in your workplace? \\
\hline & Q12. Does your company emphasize suitable rewards? \\
\hline & Q13. Do you have a strong social network? \\
\hline \multirow[t]{7}{*}{$\begin{array}{l}\text { Flexible work } \\
\text { design }\end{array}$} & $\begin{array}{l}\text { Q17. Do you have specific policies and strategies approved and } \\
\text { well communicated by the top management? }\end{array}$ \\
\hline & $\begin{array}{l}\text { Q18. How do you feel about your commitment to the } \\
\text { organizations' mission? }\end{array}$ \\
\hline & $\begin{array}{l}\text { Q19. How well does the organization forecasts project, deadlines, } \\
\text { and workloads? }\end{array}$ \\
\hline & Q20. Does your company provide coordination in teamwork? \\
\hline & $\begin{array}{l}\text { Q21. Does your organization have performance appraisal and } \\
\text { employee development methods? }\end{array}$ \\
\hline & $\begin{array}{l}\text { Q22. Does your organization update in information- and } \\
\text { communication system? }\end{array}$ \\
\hline & Q23. Do you feel that your company values your ideas and work? \\
\hline
\end{tabular}

Source: literature review

\subsection{Reliability Test}

The reliability test in research reduces the bias and more transparency for the qualitative research. If the reliability and validity of the research are not assessed, it will be impossible to describe the effects of measurement errors on theoretical relationships that are being measured (Forza, 2002) [47].

Table 2

Reliability Test

\begin{tabular}{lll} 
Variables & Cronbach's Alpha & Number of Items \\
\hline Cognitive flexibility & 0.652 & 6 \\
\hline Organizational flexibility & 0.786 & 7 \\
\hline Flexible work design & 0.757 & 7 \\
\hline
\end{tabular}

Source: Data Analysis

The values for each variable are above 7 and thus, it confirms the reliability of the factors for the study. 
Table 3

Model fit Indices for CFA

\begin{tabular}{|c|c|c|c|c|c|c|c|c|c|c|c|}
\hline Variables & $\chi^{2}$ & DF & $\mathbf{P}$ & Normed $\chi^{2}$ & GFI & AGFI & NFI & TLI & CFI & RMR & RMSEA \\
\hline $\begin{array}{l}\text { Cognitive } \\
\text { flexibility }\end{array}$ & 19.56 & 14 & 0.14 & 1.397 & 0.98 & 0.96 & 0.96 & 0.98 & 0.99 & 0.006 & 0.036 \\
\hline $\begin{array}{l}\text { Organizational } \\
\text { flexibility }\end{array}$ & 16.64 & 8 & .58 & 0.830 & 0.99 & 0.97 & 0.97 & 1.02 & 1.0 & 0.009 & 0.00 \\
\hline $\begin{array}{l}\text { Flexible work } \\
\text { designs }\end{array}$ & 17.59 & 7 & 0.01 & 2.513 & 0.98 & 0.93 & 0.97 & 0.95 & 0.98 & 0.008 & 0.071 \\
\hline $\begin{array}{l}\text { Recommended } \\
\text { value }\end{array}$ & & & & $<5$ & $>0.9$ & $>0.9$ & $>0.9$ & $>0.9$ & $>0.9$ & $<1$ & $<1$ \\
\hline
\end{tabular}

It is clear from the above table that significance level has reached for all attributes taken for the study. The measurement model is good enough to conduct this study as the value of fit indices reaches its recommended value. To confirm, the regression coefficients for each variable were also analyzed, which are tabulated in Table 4 to Table 6.

Table 4

The Regression Coefficients - Cognitive flexibility

\begin{tabular}{|c|c|c|c|c|c|}
\hline $\begin{array}{l}\text { Latent } \\
\text { Variables } \\
\text { (Dependent } \\
\text { Variable) }\end{array}$ & $\begin{array}{l}\text { Constructs } \\
\text { (Independent } \\
\text { Variables) }\end{array}$ & $\begin{array}{l}\text { Regression } \\
\text { Coefficient }\end{array}$ & $\mathbf{t}$ & $\mathbf{P}$ & $\begin{array}{l}\text { Variance } \\
\text { explained } \\
(\%)\end{array}$ \\
\hline \multirow{6}{*}{$\begin{array}{l}\text { Cognitive } \\
\text { flexibility }\end{array}$} & $\mathrm{CF} 1$ & 0.172 & 2.994 & 0.013 & 2.9 \\
\hline & CF 2 & 0.599 & 11.92 & $<0.001$ & 52.4 \\
\hline & $\mathrm{CF} 3$ & 0.423 & 7.778 & $<0.001$ & 17.9 \\
\hline & $\mathrm{CF} 4$ & 0.748 & 16.689 & $<0.001$ & 56.0 \\
\hline & CF 5 & 0.872 & 23.117 & $<0.001$ & 76.1 \\
\hline & CF 6 & 0.754 & 17.121 & $<0.0001$ & 57.5 \\
\hline
\end{tabular}

The table confirms the significance level of all measures in cognitive flexibility, except for CF 1 (0.013). The regression coefficient for all factors, except systems development opportunities, are greater than 0.4.

Table 5

The Regression Coefficient - Organizational flexibility

\begin{tabular}{cccccc}
\hline $\begin{array}{c}\text { Latent } \\
\text { Variables } \\
\text { (Dependent } \\
\text { Variable) }\end{array}$ & $\begin{array}{c}\text { Construct } \\
\text { (Independent } \\
\text { Variable) }\end{array}$ & $\begin{array}{c}\text { Regression } \\
\text { Coefficient }\end{array}$ & T & P & $\begin{array}{c}\text { Variance } \\
\text { explained } \\
\text { (\%) }\end{array}$ \\
\hline \multirow{2}{*}{ Organizational } & OF 1 & 0.724 & 15.786 & $<0.001$ & 52.4 \\
flexibility & OF 2 & 0.146 & 4.328 & 0.003 & 6.1 \\
& OF 3 & 0.599 & 11.919 & $<0.001$ & 35.9 \\
& OF 4 & 0.586 & 11.573 & $<0.001$ & 34.3 \\
& OF 5 & 0.713 & 15.394 & $<0.001$ & 50.8 \\
& OF 6 & 0.652 & 12.321 & $<0.001$ & 42.5 \\
& OF 7 & 0.787 & 16.382 & $<0.001$ & 53.2 \\
\hline
\end{tabular}


Except for OF 2 (p-value 0.003), all other attributes show their significance in organizational flexibility as the value is $<0.001$. For the factor, monotonous or timeconsuming tasks, the value is 0.1 , and for all other factors, it is above 0.4 .

Table 6

The regression Coefficients - Flexible work-designs

\begin{tabular}{lccccc}
\hline $\begin{array}{c}\text { Latent } \\
\text { Variables } \\
\text { (Dependent } \\
\text { Variable) }\end{array}$ & $\begin{array}{c}\text { Construct } \\
\text { Independent } \\
\text { Variable) }\end{array}$ & $\begin{array}{c}\text { Regression } \\
\text { Coefficient }\end{array}$ & T & P & $\begin{array}{c}\text { Variance } \\
\text { explained } \\
\text { (\%) }\end{array}$ \\
\hline & FWD 1 & 0.417 & 7.653 & $<0.001$ & 17.4 \\
& FWD 2 & 0.483 & 9.080 & $<0.001$ & 23.3 \\
Flexible & FWD 3 & 0.512 & 9.745 & $<0.001$ & 26.2 \\
work- & FWD 4 & 0.814 & 19.625 & $<0.001$ & 66.3 \\
designs & FWD 5 & 0.598 & 11.892 & $<0.001$ & 35.7 \\
& FWD 6 & 0.118 & 2.043 & 0.042 & 30.1 \\
& FWD 7 & 0.549 & 10.632 & $<0.001$ & 23.3 \\
\hline
\end{tabular}

It is clear from the table that the construct FW 6 has a regression coefficient of less than 0.4 . Hence, only this construct has no significant influence on flexible work designs. It is clear that the P-value is less than 0.001, except for the updated communication system and thus it proves the significance level of variables for flexible work-designs.

\subsection{Hypothesis Test}

As a next step, the study analyses the hypotheses, $\mathrm{H} 1$ to $\mathrm{H} 3$. The following Table 7 establishes the influence of two latent variables on flexible work design in organizations.

Table 7

Model fit Indices for CFA-Flexible work-design

\begin{tabular}{lccccccccccc}
\hline Variable & $\chi^{2}$ & DF & P & $\begin{array}{c}\text { Normed } \\
\chi^{2}\end{array}$ & GFI & AGFI & NFI & TLI & CFI & RMR & RMSEA \\
$\begin{array}{l}\text { Flexible } \\
\text { work- } \\
\text { design }\end{array}$ & 0.471 & 1 & 0.493 & 0.471 & 0.999 & 0.992 & 0.999 & 1.005 & 1.000 & 0.023 & 0.000 \\
\hline
\end{tabular}

The value of the fit indices specifies a sensible fit of the measurement model with data. Moreover, the regression coefficient for dependent and independent variables is presented in Table 8. It proves that cognitive flexibility has a significant impact on flexible work design as the standardized direct effect is greater than the recommended value (0.4) and it is clear from the above table the values like 0.76 . Similarly, the value of organizational flexibility is 0.85 and validates its significance level. Moreover, the values for reach the significance level as $\mathrm{p}$-value is $<0.001$ and 
the reliability as $0.59,0.61$, and 0.54 for cognitive responsibility, organizational flexibility, and flexible work-design, respectively.

Table 8

Regression Coefficient - Flexible work-design variables

\begin{tabular}{|c|c|c|c|c|c|c|}
\hline Path & $\begin{array}{l}\text { Regression } \\
\text { coefficient }\end{array}$ & $\mathbf{t}$ & P-value & $\begin{array}{l}\text { Variance } \\
\text { explained }\end{array}$ & $\begin{array}{l}\text { Average } \\
\text { Variance } \\
\text { Extracted }\end{array}$ & $\begin{array}{l}\text { Composite } \\
\text { Reliability }\end{array}$ \\
\hline $\begin{array}{l}\text { High-involvement } \\
\text { work systems } \rightarrow \\
\text { Flexible work- } \\
\text { design }\end{array}$ & 0.904 & 25.742 & $<0.001$ & 81.8 & & \\
\hline $\begin{array}{l}\text { Career } \\
\text { developments } \rightarrow \\
\text { CA }\end{array}$ & 0.979 & 39.171 & $<0.001$ & 95.8 & & \\
\hline $\begin{array}{l}\text { Increased } \\
\text { productivity } \rightarrow \\
\text { CA }\end{array}$ & 1.001 & 65.500 & $<0.001$ & 100.2 & 91.1 & 0.60 \\
\hline $\begin{array}{l}\text { Less turnover } \rightarrow \\
\text { CA }\end{array}$ & 0.945 & 30.725 & $<0.001$ & 89.3 & & \\
\hline
\end{tabular}

Table 8 clarifies that the p-value for all the factors has the significance level $(<0.001)$ and reliability as 0.60 .

\section{Findings and Recommendations}

Categorically, the study throws light on a new strategy development related to flexible work design in the selected healthcare sectors. The findings explain the successful accomplishment of the objectives mentioned in the introduction part as the values of all latent variables reach their significance level. The flexibility model, certainly, can act as leverage in the mindset of employees towards their motivation, engagement, and talent management (Treiu, 1992). The values of the Confirmatory Factor Analysis (Table 4), proves the association of each attribute to latent variables such as cognitive flexibility and organizational flexibility in organizations as the values reach their recommended value. Moreover, Table 5 confirms the regression analysis and significance level of cognitive flexibility in selected organizations as all the values are $<0.001$, except for $\mathrm{CF} 1$. This confirms the need for psychological contracts in organizations. Organizations should equip employees with adequate skills, knowledge, and competencies to meet the demands of the organizations through flexibility (Rosseau, 1995). Also, Table 6 proves the correlation of organizational flexibility, where all attributes, except OF 2, reached the significance level as the value is $<0.001$. It supports the view of the structural approach in the physical environment for career advancements, training, and development of informal and formal systems (Ingham, 2006). Furthermore, the regression analysis shows a positive impact on flexible work designs for all factors, except FWD 6, 
which achieved the recommended value. (Table 7). The selected models for this study underline the tangible and intangible values as well as individual and organizational facets in the selected organizations. Therefore, the findings reinforce the concepts in developing organizational and cognitive flexibilities in organizations (Atkinson, 1984).

The findings of hypothesis tests from Table 7 verify the significance of each latent variable to the flexible work-design model. Moreover, it illustrates the relationship between attributes and related variables of the study. The results confirm that cognitive flexibility in selected organizations has a significant influence on flexible work design as a standardized direct effect of this construct is 0.755 , which is more than the recommended value of 0.4 (p-value is significant). Hence, hypothesis, H1 has been accepted and it proves that employee value propositions are imperative in cognitive flexibility. Thus, the study proves that the employee values through cognitive flexibility enhance individuals' ability to widen their personal interests. This, in turn, increases career responsibilities and personal interests and reduces stress. It provides greater satisfaction and improved motivation (Ingham, 2006).

Likewise, the result of organizational flexibility is 0.85 , which attains the significance level. Thus, hypothesis, $\mathrm{H} 2$, has been accepted. While considering the relevant factors too, the outcome clarifies the significance as the p-value is $<0.001$. It proves that the management should update with the knowledge transfer internally and externally, increase the coordination with the peripheral groups by subcontracts or part-time (Scarbrough \& Swan, 2003). This can not only develop the core groups but attract new talents into the core group. This can create a hybrid of the core-periphery model. Thus, the selected companies should develop competitive management practices in creating relationships and knowledge-sharing externally. This leads to team building, self-managed work teams, High-involvement work systems. Additionally, employees feel more satisfaction, quality work-life, less turnover.

The findings from Table 8 elucidates that the p-value for all the factors, which are the outcome of flexible work design, have the significance level $(<0.001)$.

Hence, hypothesis, H3 has been accepted and this confirms that organizational strategies in work design, incentive practices, and flexibility direct to highinvolvement work processes (HIWP). By achieving organizational goals, the employees can develop their career goals by promotions and upgrading their skills. This in turn increases psychological work relationships and organizational effectiveness. Thus, it reduces staff turnover, more satisfied employees, and better quality of work life. Even though with a lot of critics in the literature on the implementation of a successful Flexi model, this study clarified the significance of cognitive and organizational flexibility in the selected companies (Burgess, 1997; Atkinson, 1984; Ingham, 2006). 


\section{Conclusions}

The present study discusses the development of a flexible work designs model in businesses and the factors to be considered by the management, in expanding their tactics, to capture full capacities. It reveals the success of proper incorporation of cognitive and organizational flexibilities. Moreover, the CFA establishes the relationship between each sub-variable to its dependent variables. The result sheds light to the employment relationship and long-term commitment in creating intrinsic and extrinsic factors. Of course, this cannot happen overnight, so it necessitates deep understanding and tactic rules. Moreover, other sectors can be taken for further studies for a wider perspective in a long-term basis. Concisely, the study can develop employees' competencies and enhancement level through structural changes. This can create change management and talent management initiatives towards a competitive advantage.

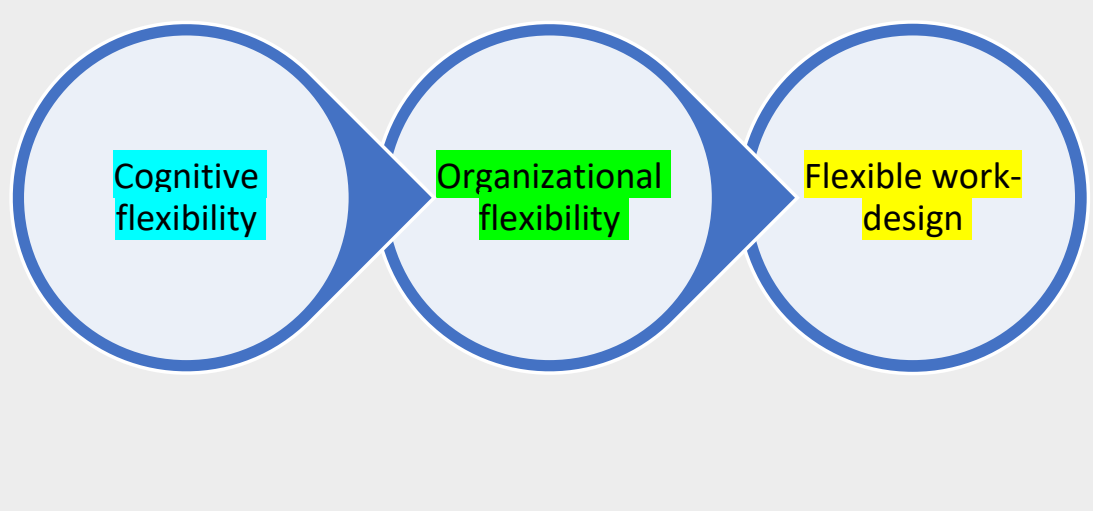

Figure 1

A flexible work-design

Source: Study from the findings

\section{References}

[1] Lawler, E. E. III, The ultimate advantage: Creating the high involvement organization, San Francicso, Jossey-Bass Publishers:xi, 1992

[2] Lei, D. and Slocum, J. W. 2005. Strategic and organisational requirements for competitive advantage, Academy of Management Executive, 19(1): 3145, 2005

[3] Mongaliso, M. P., Building competitive advantage from Ubuntu: Management lessons from South Africa, Academy of Management Executive, 15(3):23-33, 2001 
[4] Duncan, W. J., Ginter, P. M. \& Swayne, L. E., Competitive advantage and internal organizational assessment. Academy of Management Executive, 12(3)6-16, 1998

[5] Pfeffer, J. \& Ulrich, D, Competitive advantage through human resource management: Best practices or core competencies? Human Relations, 54(3):361-372, 2001

[6] Carmeli, A. \& Fishler, A., Resources, capabilities and the performance of industrial firms: A multivariate analysis, Managerial and Decision Economics, 25(6/7): 229-315, September-October, 2004

[7] Branzei, O. \& Thornhill, S., From ordinary resources to extraordinary performances: Environmental moderators of competitive advantage, Strategic Organisation, 4(1):11-14, 2006

[8] J. Kubal'a, M. Vetráková, Reasons of the Employees' Stabilization in Hotels in Slovakia, Acta Oeconomica Universitatis Selye, Vol. 6, 2018, No. 2, 90100, 2018

[9] M. Nosková, T. Peráček, Termination of Employment in the Slovak Republic as a Key Issue of HR Management. Central European Journal of Labour Law and Personnel Management, Vol. 2, No. 2, pp. 44-59, DOI: 10.33382/cejllpm.2019.03.04, 2019

[10] Hitka, M., Jarmila, S., Silivia, L., Peter, S., Dagmar, W., \& Rudolf, K., Sustainability of Human Resource Management Processes through Employee Motivation and Job Satisfaction, Acta Polytechnica Hungarica, 18(2) p: 3, 2021

[11] Ursell, G. D., Human Resource Management and labour flexibility: Some reflections based on cross-national and sectoral studies in Canada and the UK. (In Blyton, P. \& Morris, J. 1991. A flexible future? Prospects for employment and organization. Berlin: De Gruyter: 311-327:312), 1991

[12] Storey, J., Introduction: From personnel management to human resource management. (In Storey, J. (Ed). New perspectives on human resource management. London: Routledge: 1-8), 1991

[13] Mcraw, P., HRM-history, models, process and directions. (In Kramar, R., McGraw, P. \& Schuler, R. Human resource management in Australia, $3^{\text {rd }}$ ed. Melbourne: Longman: 44-86, 1997

[14] Pilbeam, S. \& Corbridge, M., People Resourcing- contemporary HRM in practice, $3^{\text {rd }}$ ed. Harlow, England: Pearson Education Ltd, 2006

[15] Wright, P. M. \& Snell, S. A., Toward a unifying framework for exploring fit and flexibility in strategic human resource management, Academy of Management Review, 23(4): 756, 1998 
[16] Nadler, D. \& Tushman, M., A diagnostic model for organizational behaviour (In Hackman, J. R., Lawler, E. E. \& Porter, L. W. (Eds.) Perspectives on behaviour in organizations. New York: McGrawHill:83-100), 1980

[17] Sanchez, R., Strategic flexibility in product competition, Strategic Management Journal, 16:135-159, 1995

[18] Treiu, T., Labour market flexibility in Europe, International Labour Review, 13(4):497-512, 1992

[19] Legge, K., Human Resource Management: Rhetorics and realities, London: Macmillan, 1995

[20] Atkinson, J., Manpower strategies for flexible organizations. Personnel Management 28-31 (August), 1984

[21] Woods, S., The transformation of work: Skill, flexibility and the labor process, London: Unwin-Hyman:1, 1989

[22] Bamber, G., Flexible work organization: Inferences from Britain and Australia, Asia Pacific Journal of Human Resource Management, 28(3):2844, 1990

[23] Ingham, J., Closing the talent management gap. Strategic HR Review, 5(3):20, 2006

[24] Rosseau, D. M, Psychological contracts in organizations: Understanding written and unwritten agreements, Thousand Oaks, C.A.: Sage, 1995

[25] ACIRRT, Australia at work: Just managing, Sydney: Prentice-Hall, 1999

[26] Scarbrough, H. \& Swan, J., Discourses of knowledge management and the learning organization, (In Easterby-Smith, M \& Lyes, M. (Eds). Handbook of organizational learning and knowledge management. Oxford: Backwell), 2003

[27] Davenport, T. H. \& Prusak, L., Tudásmenedzsment Budapest: Kossuth Kiadó, 2001

[28] Fehér, P., Tudásmenedzsment: Problémák és veszélyek. Vezetéstudomány 33(4) 36-45, 2002

[29] Sándori, Zs., Mi a tudásmenedzsment? Magyar Elektronikus Könyvtár Accessed December 11 2017, http://mek.oszk.hu/03100/03145/ html/km4.htm, 2011

[30] Bennis, W., The four competencies of leadership, Training and Development Journal, 38(8), 14-19, 1984

[31] Vasilić, N., \& Brković, P., National culture as a determinant of attitudes about leadership styles. School of Business, (2), 38-55, 2017

[32] Bushra, F., Ahmad, U., \& Naveed, A., Effect of transformational leadership on employees' job satisfaction and organizational commitment in banking 
sector of Lahore (Pakistan) International Journal of Business and Social Science, 2(18), 261-267, 2011

[33] Gill, A. S., Flaschner, A. B., \& Shacha, M., Mitigating stress and burnout by implementing transformational-leadership, International Journal of Contemporary Hospitality Management, 18(6), 469-481, 2006

[34] Nemanja, B., Agnes, S., Slavomir, M., Zoran, S., Marko, A., A Survey on Relationship between Leadership Styles and Leadership Outcomes in the Banking Sector in Serbia. Acta Polytechnica Hungarica, 16(1) 3-4, 2019

[35] Graen, M. Uhl-Bien, The Transformation of Work Group Professionals into Self-Managing and Partially Self-Designing Contributors: Toward a Theory of Leadership-Making, Journal of Management Systems, 3, (3) pp. 25-39, 1991

[36] G. Graen, M. Uhl-Bien, Relationship-based Approach to Leadership: Development of Leader-Member Exchange (LMX) Theory of Leadership over 25 Years: Applying a Multi-Level Multi-Domain Perspective, The Leadership Quarterly, 6, (2) pp. 219-247, 1995

[37] M. Uhl-Bien, Relational Leadership Theory: Exploring the Social Processes of Leadership and Organizing, Leadership Quarterly, 17 (6) pp. 654-676, 2006

[38] Valentin, K., Leposava, G., Dejan, M., The Influence of Leader-Member Communication on Organizational Commitment in a Central European Hospital. Acta Polytechnica Hungarica, 12(3), 2-3, 2015

[39] Kelliher \& Anderson, For better or for worse? An analysis of how flexible working practices influence employees' perceptions of jog quality. The International Journal of Human Resource Management, 19(3) (March):419431, 2008

[40] Szabó, K., Hámori, B, Information Economy, Akadémia, Budapest, 2006

[41] Gordery \& Parker, Work Organization, (In Boxall, P., Purcell, J., \& Wright, P. (Ed). The Oxford Handbook of Human Resource Management: A Critical Text: 187-209. Oxford: Oxford University) 2007

[42] Thompson, P. \& Mchugh, D., Work Organization: A critical introduction, $2^{\text {nd }}$ ed. London: Macmillan Business: 174-175, 1995

[43] Kiss, P., Demand for Competencies of Graduates and Work Satisfaction, In: Garai, O., Horváth, T, Kiss, L., Szép, L., Veroszta, Zs. (eds.), Graduate T. Tóth-Téglás et al. An Analysis of Employer Requirements of University Graduates - 188 - Survey IV, 2011, Education, Budapest, 2011

[44] Díaz-Fernandez M., López-Cabrales A., Valle-Cabrera R., A Contingent Approach to the Role of Human Capital and Competencies in Firm Strategy, Business Research Quarterly, 17, pp. 205-222, 2014 
[45] Amador, L. B., Nicolás Á. L., Vila L. E., Education and Competency Mismatches: Job Satisfaction Consequences for Workers, XVI Jornadas ASEPUMA - IV Encuentro International Rect@VolActas_16Issue1:105, 2013

[46] Burgess, J., The flexible firm and the growth of non-standard employment, Labour \& Industry, 7(3):85-102, 1997

[47] Forza, C., Survey Research in Operations Management: A Process-based Perspective. International Journal of Operations and Production Management, 22 (2), pp. 152-194, 2002 